ROCZNIKI NAUK SPOŁECZNYCH

Tom 11(47), numer 1 - 2019

DOI: http://dx.doi.org/10.18290/rns.2019.47.1-3

AGNIESZKA LEGUCKA

\title{
MIEJSCE UKRAINY \\ W STOSUNKACH ROSYJSKO-AMERYKAŃSKICH PO 2014 ROKU
}

Stosunki rosyjsko-amerykańskie charakteryzuje rywalizacja ${ }^{1}$. Zdaniem Marka Menkiszaka Rosja ma potencjał szkodzenia i w ten sposób stara się być dostrzeżona w relacjach z Amerykanami. Potencjał ten jest „,na tyle duży, że nie pozostawia USA obojętnymi, ale na tyle mały, że nie jest na razie w stanie doprowadzić do zmiany jakiegoś z priorytetów polityki amerykańskiej”" Swojej obojętności administracja amerykańska nie wykazała po 2014 r., kiedy zwrot „ku Azji” Baraka Obamy został wstrzymany na rzecz powrotu do tradycyjnego kierunku amerykańskiej polityki zagranicznej - Europy, wyrażającego się m.in. we wzmocnieniu wschodniej flanki NATO. Pytania, jakie stawia sobie niniejszy artykuł, są następujące: czy Ukraina jest przedmiotem czy podmiotem rosyjsko-amerykańskiej rywalizacji? Jakie interesy ma Rosja i USA w tym państwie? I wreszcie, jakie miejsce zajmuje Ukraina w polityce zagranicznej obu państw? Okres, jakiemu poświęcona jest analiza, to czas przewartościowania polityki państw zachodnich względem Rosji, która dokonała nielegalnej aneksji Krymu i wsparła separatystów w Donbasie. W USA czas ten przypada na ostatnie dwa

Dr hab. AgnieszKa LeguCKA - Polski Instytut Spraw Międzynarodowych, Wydział Biznesu i Stosunków Międzynarodowych, Akademia Finansów i Biznesu Vistula; adres do korespondencji: ul. Stokłosy 3, 02-787 Warszawa; e-mail: a.legucka@vistula.edu.pl; ORCID iD: https://orcid. org/0000-0002-9438-2606

${ }^{1}$ A. WŁodKowsKa-BAGAn, Rywalizacja mocarstw na obszarze poradzieckim, Warszawa: Difin 2013; A.E. STEnT, The Limits of Partnership. US-Russian Relationship in the Twenty-First Century, Princeton: Princeton University Press 2015; M. KaCZMARSKI, Polityka zagraniczna Rosji wobec USA, w: S. Bieleń, M. Raś (red.), Polityka zagraniczna Rosji, Warszawa: Difin 2008, s. 48-49; T. KAPUŚNIAK, Ukraina jako obszar wpływów międzynarodowych po zimnej wojnie, WarszawaLublin: Instytut Europy Środkowo-Wschodniej 2008.

${ }^{2}$ M. MenkiszaK, Najlepszy nieprzyjaciel Rosji. Rosyjska polityka wobec USA w epoce Putina, „Punkt Widzenia OSW” 62(2017) (luty), s. 49-50. 
lata prezydentury Baraka Obamy, burzliwą kampanię wyborczą Hilary Clinton i Donalda Trumpa oraz jego rządy. W Rosji po 2014 r. nastąpił niezwykły wzrost popularności prezydenta Władimira Putina (powyżej 80\%), który na fali „powrotu Krymu do macierzy" umocnił się w systemie władzy w Rosji. Jak podkreśla Nikołaj Pietrow, „Putin jako główne źródło wszelkiej legitymizacji znacznie mniej zależy od elit niż uprzednio. One z kolei bardziej zależą od niego niż od obywateli. Począwszy od wydarzeń krymskich - trwa radykalna wymiana rosyjskich elit politycznych, raczej strategiczna niż sytuacyjna"3. W kontekście wydarzeń ukraińskich - uwarunkowania wewnętrzne rosyjskiej i amerykańskiej polityki miały znaczenie nie mniejsze niż rywalizacja na arenie międzynarodowej.

\section{SPRZECZNE INTERESY}

Rosja ma żywotne interesy na Ukrainie. Po pierwsze, są one związane z bezpieczeństwem ekonomicznym państwa. Ukraina nadal jest ważnym państwem tranzytowym dla rosyjskich surowców energetycznych, z których pochodzi 50-60\% dochodów do budżetu federalnego państwa rosyjskiego. Po drugie, rosyjskie interesy dotyczą także stabilności społeczno-politycznej wewnątrz Rosji, gdyż przykład kolorowych rewolucji jest z perspektywy rosyjskiej elity postrzegany jako zagrożenie dla przywództwa w Rosji. Trzeci interes, jaki Rosja ma na Ukrainie, jest związany z jej bezpieczeństwem militarnym, gdyż władze rosyjskie uważają, że perspektywa wejścia tego państwa do NATO byłaby groźna dla FR. Po czwarte, mało transparentna ukraińska gospodarka jest dla rosyjskiego kapitału lepszym miejscem do inwestycji i robienia biznesu niż gospodarka zintegrowana z UE i nieprzychylna Rosji. Z powyższych powodów władze rosyjskie postrzegają Ukrainę priorytetowo w przestrzeni postsowieckiej, zarówno jako największe terytorialnie państwo, jak również miejsce, które z przyczyn strategicznych powinno - zdaniem Rosji - znajdować się w rosyjskiej strefie wpływów - lub przynajmniej w strefie buforowej, która byłaby dla Rosji do zaakceptowania.

USA nie mają żywotnych interesów na Ukrainie. Po pierwsze, Ukraina jest dla nich ważna z punktu widzenia powstrzymywania Rosji w skali regionalnej i globalnej. Po drugie, w interesie USA jest utrzymanie istniejącego ładu międzynarodowego w Europie, polegającego na przestrzeganiu integralności terytorialnej państw i równowadze sił, np. na Morzu Czarnym. Terytorium Ukrainy - z punktu widzenia NATO - nie powinno być zmilitaryzowane przez Rosję.

\footnotetext{
${ }^{3}$ N. PIETRow, Rosja przechodzi do natarcia, „Polski Przegląd Dyplomatyczny” 2(2018), s. 41.
} 
Po trzecie, demokratyzacja i pozytywne przemiany wewnętrzne na Ukrainie zwiększają wpływy amerykańskie w regionie. Po czwarte, przemiany polityczne mogą przyczynić się do wzrostu wymiany handlowej, w tym współpracy energetycznej między Ukrainą i podmiotami z USA.

Różnica między żywotnymi interesami Rosji a nieżywotnymi USA na Ukrainie jest taka, że mimo zaprzeczeń rosyjskich władz, położenie geograficzne i sytuacja wewnętrzna państwa ukraińskiego jest egzystencjalnie ważna dla Rosji jako imperium, jego gospodarki i ciągłości władzy. Sprzeczność interesów między dwoma mocarstwami wynika natomiast z postrzegania Ukrainy jako przedmiotu rywalizacji, a nie jako jej podmiotu, który może samodzielnie realizować cele swojej polityki zagranicznej.

\section{UKRAINA W POLITYCE ZAGRANICZNEJ USA I ROSJI}

(2013-2016)

Początkowo administracja Baracka Obamy stwarzała Rosji szansę na nowy początek we wzajemnych relacjach, tzw. reset. Obama nie traktował stosunków z Rosją priorytetowo. Kraj ten był ważnym uczestnikiem stosunków międzynarodowych, ale z punktu widzenia amerykańskiej polityki globalnej drugoplanowym, wręcz peryferyjnym ${ }^{4}$. Stanom Zjednoczonym wydawało się, że dzięki współpracy z Rosją uda się osiągnąć ważne cele w polityce zagranicznej: ograniczyć proliferację broni masowego rażenia, tym samym zwiększyć bezpieczeństwo nuklearne USA, porozumieć się w sprawie Iranu i Korei Północnej, a nawet załagodzić sytuację na Bliskim Wschodzie i w Afryce Północnej. Sekretarz stanu Hillary Clinton tłumaczyła, że Amerykanie powinni skoncentrować się na realizacji amerykańskich interesów we współpracy z Rosją tam, gdzie jest to możliwe. Ukraina nie znajdowała się wśród państw, które były istotne z punktu widzenia administracji Baracka Obamy. Pierwsza kadencja Obamy to próba znalezienia kompromisu z Rosją, która zaowocowała m.in. uruchomieniem tzw. Północnej Drogi dla transportu niewojskowych towarów z Afganistanu, nowym porozumieniem w dziedzinie ograniczenia i kontroli strategicznych arsenałów jądrowych (Nowy START), współpracą w sprawie Iranu oraz Libii, a także finalizacją akcesji Rosji do Światowej Organizacji Handlu 5 . s. 54.

${ }^{4}$ Z. Lewicki, Dziedzictwo Obamy - próba oceny, „Polski Przegląd Dyplomatyczny” 1(2017),

5 A. LegucKa, Polityka Baracka Obamy wobec Rosji, „Polski Przegląd Dyplomatyczny” 2(2017), s. 109-129. 
Pierwsze demonstracje na Majdanie w listopadzie 2013 r., związane z niepodpisaniem przez prezydenta Janukowycza umowy stowarzyszeniowej między Ukrainą a Unią Europejską, były obserwowane przez Amerykanów z dystansem. Inaczej było w Rosji. Eskalacja napięć wewnętrznych, coraz liczniejsze zgromadzenia w Kijowie i innych miastach, a wreszcie żądania ustąpienia Janukowycza, zostały zinterpretowane w Moskwie jako kolejna „kolorowa rewolucja”, zagrożenie dla politycznego status quo. Odpowiedzialnością za wydarzenia na Majdanie Putin obciążył więc Stany Zjednoczone i Unię Europejską, które miały jego zdaniem dążyć w ten sposób do uderzenia w samą Rosję. W szczególności Putin zapamiętał wystąpienia Hilary Clinton z lat wcześniejszych $(2011,2012)$, kiedy demonstrowano w Moskwie, a amerykańska dyplomatka przekonywała o potrzebie wsłuchiwania się $\mathrm{w}$ głos obywateli. Władze rosyjskie jednoznacznie wówczas zinterpretowały te głosy, oskarżając USA o podżeganie do przewrotu wewnętrznego w Rosji. Dlatego podczas „rewolucji godności” rosyjskie środki masowego przekazu, głównie telewizja, stworzyły i promowały obraz ukraińskiego wroga, którego sponsorują amerykańskie władze, w tym np. ambasada. Putin poszedł dalej niż Silvio Berlusconi, twierdzący niegdyś, że „to, czego nie ma w TV, nie istnieje”. Przywódca Rosji uznał, że to, „co nie istnieje, można wykreować jako rzeczywistość dzięki sile telewizji”. Odsunięcie Janukowycza od władzy w lutym 2014 r. przez protestujących na kijowskim Majdanie liderów opozycji zostało w Rosji przedstawione jako przewrót neonazistowskiej junty, która miała na celu podważenie praw mieszkańców Krymu i ludności rosyjskojęzycznej na Ukrainie. W związku z tym 1 marca 2014 r. prezydent Władimir Putin zwrócił się do Rady Federacji z prośbą o zatwierdzenie użycia Sił Zbrojnych FR na terytorium Ukrainy „do czasu normalizacji sytuacji społeczno-politycznej w tym państwie"7.

Natomiast aneksja Krymu w marcu 2014 r. oraz wsparcie nieregularnych oddziałów we wschodniej części Ukrainy - w Donbasie - były impulsem do przebudzenia się Ameryki w relacjach z Rosją. Rosja na terenie Ukrainy rozpoczęła wówczas tzw. wojnę hybrydową, używając metod konwencjonalnych i niekonwencjonalnych, w imię koncepcji „ruskiego miru” i projektu Noworosji, czyli odtworzenia protektoratu Rosji od Odessy do Charkowa. Podbudowana względnie szybką i udaną kampanią na Krymie, mając nadzieję na słabość militarną Ukrainy i wsparcie ze strony ludności rosyjskojęzycznej, liczyła na sukces koncepcji Noworosji. Nie było jasne, w którym momencie Władimir Putin się za-

${ }^{6}$ S. Ostrovsky, The Invention of Russia. The Journey from Gorbachev's Freedom to Putin's War, London: Atlantic Books 2015, s. 7.

${ }^{7}$ Cyt. za: P. BAJOR, ,, Operacja Krym” - aneksja pótwyspu i jej konsekwencje, ,Rocznik Instytutu Europy Środkowo-Wschodniej” 2(2014), z. 2, s. 42. 
trzyma i jakie konsekwencje będzie miała „rosyjska wiosna” w tej części Europy $^{8}$. Obama dostrzegał, jak się wydaje, skutki działań rosyjskich nie tylko dla Ukrainy, lecz także dla stabilności ładu międzynarodowego w ogóle. Dotyczyło to m.in. skutków pogwałcenia memorandum budapeszteńskiego z 1994 r., w którym USA, Wielka Brytania i Rosja zgodziły się szanować suwerenność i integralność terytorialną Ukrainy, kiedy ta oddawała swój arsenał nuklearny Federacji Rosyjskiej. Swoimi działaniami na Krymie i na wschodniej Ukrainie Putin podważał wiarygodność amerykańskich i europejskich zobowiązań wobec państwa, które dobrowolnie zgodziło się na rezygnację z posiadania broni jądrowej - co mogło mieć destrukcyjny wpływ na starania o powstrzymanie programów jądrowych takich państw, jak Iran czy Korea Północna.

Wiosną 2014 r. w reakcji na aneksję Krymu USA zawiesiły kontakty handlowe z Rosją, przerwały współpracę wojskową oraz wprowadziły sankcje dla osób, które były zaangażowane w działania naruszające suwerenność i integralność terytorialną Ukrainy. 3 kwietnia 2014 r. w Kongresie przyjęto ustawę o wsparciu rządu Ukrainy w walce z Rosją (Support for the Sovereignty, Integrity, Democracy, and Economic Stability of Ukraine Act $)^{9}$. Na tej podstawie Departament Stanu zamroził aktywa ośmiu banków i ponad trzydziestu firm, ograniczył możliwość wjazdu na teren USA dla osób z bliskiego kręgu Putina oraz wprowadził sankcje sektorowe ${ }^{10}$. Oznaczało to potępienie aneksji Krymu, uznanie integralności terytorialnej Ukrainy, poparcie dla nowej administracji w Kijowie oraz uruchomienie pomocy finansowej ${ }^{11}$. Amerykanie dostrzegali również potrzebę wsparcia militarnego Ukrainy, chociaż Obama wykluczał możliwość użycia wojsk amerykańskich w tym konflikcie. Administracja Ameryki zmniejszyła się do tej pory, aby wysłać śmiertelną pomoc wojskową dla Ukrainy, ale zapewniła nieśmiercionośną pomoc. W kwietniu 2014 r. Biały Dom wyasygnował $18 \mathrm{mln}$ dol. pomocy na rzecz bezpieczeństwa dla Ukrainy. W kolejnych miesiącach suma doszła do 33 mln dol. m.in. na rzecz Państwowej Straży Granicznej Ukrainy ${ }^{12}$.

Ważne wsparcie dla Ukrainy ze strony USA było udzielane za pośrednictwem Sojuszu Północnoatlantyckiego, chociaż nie było zgody między członkami

\footnotetext{
${ }^{8}$ S. Ostrovsky, The Invention of Russia, s. 338.

${ }^{9}$ Sankcje USA, w: Sankcje i Rosja, red. J. Ćwiek-Karpowicz, S. Secrieru, Warszawa: PISM 2015, s. 26.

${ }^{10}$ Tamże.

${ }^{11}$ Support for the Sovereignty, Integrity, Democracy, And Economic Stability of Ukraine Act of 2014, „Public Law” 2014, 113-195, Apr. 3, www.congress.gov

12 P. Belkin, E.D. Mix, S. Woenrel, NATO: Response to the Crisis in Ukraine and Security Concerns in Central and Eastern Europe, „Congressional Research Service”, 31 lipca 2014 r.
} 
W sprawie dostarczania Ukrainie broni śmiercionośnej ${ }^{13}$. Podczas szczytu NATO w Newport 4-5 września $2014 \mathrm{r}$. powrócono do koncepcji tradycyjnych funkcji obronnych i wzmocnienia wschodniej flanki Sojuszu ${ }^{14}$. Prezydent Petro Poroszenko przeprowadził wówczas serię rozmów z zachodnimi politykami, zorganizowano także posiedzenie Komisji NATO-Ukraina ${ }^{15}$. Po spotkaniu wydano komunikat, w którym oskarżono Rosję o naruszenie suwerenności i integralności terytorialnej Ukrainy oraz o bezprawną aneksję Krymu ${ }^{16}$. Wsparcie zadeklarował amerykański prezydent, przekonując, że „NATO powinno przyjąć konkretne zobowiązania wobec Ukrainy, aby pomóc jej w modernizacji i wzmocnieniu jej armii" ${ }^{17}$. Dowódca sił NATO w Europie, generał Philip Breedlove, mówił, że Zachód nie powinien wykluczać opcji militarnej na Ukrainie. W późniejszych wywiadach potwierdził potrzebę wykorzystania wszystkich instrumentów nacisku na Rosję, która, jego zdaniem, przerzucała na Ukrainę coraz to nowe siły ${ }^{18}$.

W Strategii bezpieczeństwa narodowego USA z 2015 r. Rosję określono jako agresywną i ostrzegano UE przed zależnością energetyczną. Doceniono potrzebę wprowadzenia sankcji jako próby nacisku na Rosję, aby odstąpiła od polityki nierespektowania integralności terytorialnej innych państw i naruszania porządku międzynarodowego ${ }^{19}$. Wprowadzenie sankcji przez Stany Zjednoczone i Unię Europejską było dla Rosji dużym zaskoczeniem, chociaż specjaliści przekonywali, że dla gospodarki rosyjskiej większym obciążeniem stały się wprowadzone przez władze rosyjskie kontrsankcje. Bez wątpienia najpoważniejszym problemem był spadek ceny ropy na światowych rynkach ${ }^{20}$. Spowodowało to w $2014 \mathrm{r}$. 46-procentowy spadek wartości rubla w stosunku do amerykańskiego dolara. Centralny Bank Rosji został zmuszony do uruchomienia 27,2 mld dol. (w październiku 2014 r.) i 11,9 mld dol. (w grudniu 2014 r.) w celu stabilizacji systemu finansowego państwa i wsparcia waluty ${ }^{21}$.

Konflikt zbrojny na Ukrainie zmienił sytuację w Europie. Niepowodzenie projektu Noworosji i wzmocnienie wschodniej flanki NATO Władimir Putin

${ }^{13}$ A. LEGUCKA, The NATO-Ukraine Relations After the Annexation of Crimea, „Ukraine Analytica" 2(2017), s. 42-49.

${ }^{14}$ Generat USA: Zostaniemy w krajach baltyckich, jak dlugo będzie trzeba, PAP, 9 marca $2015 \mathrm{r}$.

15 Rasmussen: Kraje NATO przeznacza 15 mln euro na wsparcie dla Ukrainy, „Newsweek”, 4 września $2014 \mathrm{r}$.

${ }_{16}$ P. BAJOR, Ukraina chce do NATO, „Nowa Europa Wschodnia”, 7 września 2014 r., Www.new.org.pl

${ }^{17}$ B. KorAnYI, S. Holland, D. MARDISTE, Obama says NATO must help strengthen Ukraine's military, „Reuters”, 3 września $2014 \mathrm{r}$.

${ }^{18}$ Wywiad NATO alarmuje: Rosjanie przerzucaja nowe sity na Ukraine, www.polskieradio.pl

${ }^{19}$ National Security Strategy, The White House, luty 2015, http://nssarchive.us

${ }^{20}$ Sankcje i Rosja, red. J. Ćwiek-Karpowicz, S. Secrieru, s. 31.

${ }^{21}$ www.focus-economics.com/countries/russia. 
postanowił zrekompensować w innym regionie: na Bliskim Wschodzie. Rada Federacji 30 września 2015 r. wyraziła zgodę na wysłanie rosyjskich wojsk do Syrii, aby walczyć z Państwem Islamskim na prośbę prezydenta Baszara al-Asada. Pomimo przejściowych trudności, jakie dla stosunków rosyjsko-tureckich stworzyło zestrzelenie przez Turcję rosyjskiego samolotu nad jej terytorium, Moskwa zawarła taktyczny sojusz z Ankarą. Mając po swojej stronie zarówno Turcję, jak i Iran, Rosja przyspieszyła operację militarną, aby już w roli mediatora móc negocjować warunki porozumienia na Bliskim Wschodzie z nowym prezydentem Stanów Zjednoczonych. Obamowska koncepcja leadership from behind się nie sprawdziła. Ostatni rok prezydentury Baracka Obamy to $\mathrm{z}$ jednej strony kampania wyborcza $\mathrm{z}$ rosyjskimi manipulacjami $\mathrm{w}$ tle, a $\mathrm{z}$ drugiej wysiłki w celu odbudowania wiarygodności międzynarodowej, szczególnie w Europie.

Podczas szczytu w Warszawie w lipcu 2016 r. potwierdzono wagę artykułu 5 traktatu waszyngtońskiego, głoszącego spójność i wiarygodność Sojuszu Północnoatlantyckiego. Rosjanie demonstrowali niezadowolenie w związku z pomysłami wzmocnienia wschodniej flanki, ogłaszając rozlokowanie Iskanderów w obwodzie kaliningradzkim oraz zwiększając liczbę dużych ćwiczeń wojskowych u granic Sojuszu, wielokrotnie naruszając przestrzeń powietrzną państw natowskich. Rosję zaczęto postrzegać jako bezpośrednie zagrożenie dla amerykańskiego bezpieczeństwa narodowego dopiero po przegranej Hillary Clinton w listopadzie 2016 r. Okazało się, że „peryferyjna” Rosja, za pomocą wywiadu i ataków hakerskich, była w stanie oddziaływać na obywateli Stanów Zjednoczonych i wpływać na sytuację wewnętrzną USA. Można stwierdzić, że Amerykanie obudzili się zbyt późno. Podczas ostatniej podroży po Europie Wschodniej wiceprezydent Stanów Zjednoczonych Joe Biden w ostrych słowach wypowiadał się na temat Rosji. W czasie wizyty na Ukrainie, na terenach ogarniętych konfliktem zapewniał, że Stany Zjednoczone nie zostawią Ukrainy samej sobie i będą bronić demokracji w tym państwie ${ }^{22}$. W styczniu 2017 r. Obama przedłużył na kolejny rok sankcje wobec Rosji związane z agresją w Ukrainie. Pod koniec 2016 r. Obama podjął ponadto decyzję o wydaleniu z USA rosyjskich dyplomatów podejrzewanych o udział w infiltracji kampanii Partii Demokratycznej i równoległą pracę dla rosyjskiego wywiadu. Reakcja Putina świadczyła o jego lekceważeniu Obamy - zamiast w odwecie wydalić amerykańskich dyplomatów z terytorium Rosji, zaprosił ich dzieci na Kreml na bożonarodzeniową choinkę (a przy tym stanowiła gest dobrej woli wobec nowego amerykańskiego

${ }^{22}$ On Final Ukraine Trip, Biden Urges Trump Administration to Keep Russia Sanctions, „The Guardian”, 16 stycznia 2017 r. 
prezydenta elekta Donalda Trumpa). W trakcie kampanii wyborczej otwarcie mówił on o możliwościach współpracy z Federacją Rosyjską.

\section{UKRAINA W POLITYCE USA I ROSJI}

(2017-2018)

Od momentu dojścia do władzy Donalda Trumpa Rosja kilkakrotnie przedstawiała ofertę współpracy zarówno w odniesieniu do Syrii, Korei Północnej, jak i Ukrainy. Celem miało być uznanie szczególnej roli Rosji w regulowaniu sytuacji międzynarodowej, podniesienie jej pozycji i prestiżu w relacjach z USA, a w praktyce - zniesienie sankcji. W Europie Rosja liczyła na milczące przyzwolenie strony amerykańskiej dla aneksji Krymu, jeżeli zawieszone zostaną działania zbrojne na wschodzie Ukrainy (w Donbasie).

Początkowo wydawało się, że deklaracje o specjalnych relacjach amerykańsko-rosyjskich zostaną zrealizowane. Podczas pierwszej rozmowy telefonicznej 28 stycznia 2017 r. prezydenci USA i Rosji do ważnych obszarów kooperacji zaliczyli Bliski Wschód, w tym uregulowanie konfliktu izraelsko-palestyńskiego i syryjskiego, nierozprzestrzenianie broni masowego rażenia oraz powrót do rozmów na temat programów nuklearnych Iranu i Korei Północnej ${ }^{23}$. Sprawa Ukrainy nie pojawiła się podczas rozmów, co oznaczało, że była to dla obu stron zbyt poważna. Niemniej Rosjanie nadal liczyli na więcej. Sekretarzem stanu w administracji Białego Domu został Rex Tillerson, były dyrektor generalny ExxonMobil, spółki, która kilkakrotnie lobbowała na rzecz zniesienia sankcji wobec Rosji ${ }^{24}$. Tillerson w 2012 r. otrzymał Order Przyjaźni od Władimira Putina za duży wkład w rozwój i umocnienie współpracy z Federacją Rosyjską, ale w 2014 r. musiał przerwać inwestycje swojej firmy w Rosji w związku z amerykańskimi sankcjami ${ }^{25}$. Tymczasem 2 lutego 2017 r. Departament Skarbu złagodził niektóre obostrzenia dotyczące transakcji między amerykańskimi firmami i FSB (na zasadzie licencji) ${ }^{26}$. Było to zaskakujące, gdyż sankcje wprowadzone przez Baracka Obamę ograniczały wszelkie kontakty z rosyjskimi służbami bez-

${ }^{23}$ D.B. BAEL, If Trump Tries to Make a Deal with Putin, He's Already Lost, „Foreign Policy”, 30 stycznia $2017 \mathrm{r}$.

${ }^{24}$ A. Vaughan, Choice of Rex Tillerson Could Revive US-RussiaEenergy Summits, „The Guardian", 12 stycznia 2017 r.

${ }^{25}$ Ukaz priezidienta Rossijskoj Fiedieracyi ot 30.09.2012 g., nr 1342 o nagrażdienii gosudarstwiennymi nagradami Rossijskoj Fiedieracyi inostrannych grażdan, 30 września 2012 r., www.kremlin.ru

${ }^{26}$ General License No. 1 Authorizing Certain Transactions with the Federal Security Service, 2 lutego 2017 r., www.treasury.gov 
pieczeństwa $^{27}$. Obserwatorzy obawiali się, że Trump będzie realizował interesy rosyjskie, także w polityce zagranicznej, a państwem, które będzie elementem targów, może okazać się Ukraina.

Tym, co ograniczyło zbliżenie Trumpa z Rosją, były insynuacje o jego możliwych kontaktach przed wyborami prezydenckimi z Rosjanami. Potwierdził to skandal, który wybuchł po ujawnieniu rozmów doradcy ds. bezpieczeństwa, Michaela Flynna, i jego rezygnacja 13 lutego 2017 r. Miesiąc przed objęciem funkcji niezgodnie z prawem negocjował z ambasadorem Federacji Rosyjskiej w USA, Siergiejem Kislakiem, możliwość zniesienia sankcji wobec Rosji. Oznaczało to, że kolejne otwarcie w stosunkach rosyjsko-amerykańskich znacznie się opóźni, o ile w ogóle będzie możliwe, gdyż podważyło wiarygodność nie tylko Flynna, lecz także samego prezydenta, któremu zarzucano zbyt bliskie związki z Rosją.

Administracja Białego Domu, a także Kongres byli przekonani o potrzebie zaostrzenia kursu polityki wobec Rosji. Zarówno amerykańska ambasador w ONZ Nikki Haley, jak i sekretarz stanu Rex Tillerson wyraźnie zapowiedzieli kontynuację wywierania presji na Rosję, aby wycofała się z zaanektowanego Krymu, jak również ze wsparcia dla oddziałów w Donbasie. Już 16 marca 2017 r. Departament Stanu wydał oświadczenie, w którym potępił działania Rosji na Krymie i potwierdził integralność terytorialną Ukrainy ${ }^{28}$. Podczas wizyty Tillersona w Moskwie 12 kwietnia 2017 r. obie strony zadeklarowały poparcie dla porozumień mińskich i odtworzenie dwustronnego mechanizmu konsultacyjnego między specjalnym przedstawicielem prezydenta Rosji i przedstawicielem Departamentu Stanu.

Równolegle w obu izbach amerykańskiego parlamentu rozpoczęły się prace nad ograniczeniem Trumpowi możliwości samodzielnego znoszenia obostrzeń względem Federacji Rosyjskiej. Amerykańscy senatorowie z obu partii 10 lutego 2017 r. wnieśli do Kongresu projekt ustawy ws. skodyfikowania sankcji wobec Rosji. Prace nad ustawą sfinalizowane zostały latem. Nie przeszkodziło w tym spotkanie Putina z Trumpem 11 lipca, przy okazji szczytu G20, podczas którego nie poruszono kontrowersyjnych kwestii Ukrainy i sankcji ${ }^{29}$. Izba Reprezentantów 25 lipca zdecydowaną większością głosów (419 do 3), a dwa dni później Senat (98 do 2) przegłosowały dokument przeciwko ,agresywnym państwom,

\footnotetext{
${ }^{27}$ R. SHABAD, Trump Administration Relaxes U.S. Sanctions on Russia Imposed under Obama, 2 lutego 2017 r., www.cbsnews.com

${ }^{28}$ Reaffirming U.S. Commitment to a Sovereign and Whole Ukraine on the Third Anniversary of Russia's Crimean "Referendum", Washington, DC, 16 marca 2017 r., https://www.state.gov

${ }^{29}$ A.M. DynER, Spotkanie Trump-Putin w Hamburgu, „Komentarz PISM” 38(2017), 11 lipca $2017 \mathrm{r}$.
} 
które naruszają bezpieczeństwo swoich sąsiadów”, w którym wymieniono Rosję, Koreę Północną i Iran. Była to porażka prestiżowa Federacji Rosyjskiej. Zrównano ją bowiem z dawnymi państwami „osi zła” za czasów George’a W. Busha. Trump 2 sierpnia 2017 r. złożył swój podpis na tym dokumencie, lecz w oświadczeniu podkreślił, że: „Ustawa jest wadliwa, gdyż wkracza w kompetencje władzy wykonawczej i utrudnia prowadzenie negocjacji [...], co może prowadzić do zbliżenia Chin, Rosji i Korei Północnej. [...] Jako prezydent potrafię robić lepsze interesy z państwami niż Kongres" ${ }^{30}$. Dało to jasny sygnał, że w razie chęci polepszenia relacji z Rosją politycy obu partii Kongresu będą prezydentowi przeciwni $^{31}$.

W odpowiedzi MSZ Rosji wydało oświadczenie, w którym podważyło legalność amerykańskich restrykcji, zarzucając Stanom Zjednoczonym stosowanie nieuczciwej konkurencji w handlu światowym (chodziło głównie o Nord Stream 2) ${ }^{32}$. Poinformowano też, że od 1 września 2017 r. liczba dyplomatów USA zostanie zredukowana do 455 (odpowiednio do liczby rosyjskich przedstawicieli dyplomatycznych w USA). Ponadto zobowiązano Amerykanów do opuszczenia pomieszczeń w Moskwie i rezydencji w Srebrnym Borze do 1 sierpnia 2017 r. W ramach retorsji władze amerykańskie zobowiązały Rosjan do opuszczenia konsulatu generalnego w San Francisco ${ }^{33}$.

We wrześniu Federacja Rosyjska przedstawiła w ONZ propozycję operacji pokojowej na Ukrainie, która miałaby być rozmieszczona na linii granicznej między obwodami ługańskim i dniepropietrowskim ${ }^{34}$. Szczegółami jej mandatu mieli zająć się specjalni przedstawiciele, ze strony Rosji - Władisław Surkow, ze strony amerykańskiej - Kurt Volker. Tymczasem Departament Stanu w grudniu 2017 r. po kilku latach wątpliwości zgodził się sprzedać Ukrainie broń obronną (z czym wstrzymywał się Obama) $^{35}$. Oznaczało to, że Amerykanie nie zrezygnują ze wsparcia udzielanego temu państwu i rywalizacji z Rosją na obszarze postsowieckim.

\footnotetext{
${ }^{30}$ K. COllins, J. Herb, D. Diaz, Trump Signs Bill Approving New Sanctions Against Russia, „CNN”, 8 lutego $2017 \mathrm{r}$.

${ }^{31}$ The Trump Administration and the Russia Probes, „Strategic Comments” 23(2017), nr 7.

32 A. Dąbrowski, A. Legucka, Sankcje USA wobec Rosji, „Biuletyn PISM” 73(2017), 31 lipca 2017 r., www.pism.pl

${ }^{33}$ R. SAKwa, U.S.-Russian Relations in the Trump Era, „Insight Turkey” 19(2017), nr 4, s. 24.

${ }^{34}$ A.M. Dyner, D. Szeligowski, Perspektywa operacji pokojowej ONZ w Donbasie, „Biuletyn PISM" 94(2017), 5 października $2017 \mathrm{r}$.

$35 \mathrm{~W}$ szczególności dotyczyło to sprzedaży tzw. pocisków przeciwczołgowych Javelin. J. Rogin, Trump Administration Approves Lethal Arms Sales to Ukraine, „Washington Post”, 20 grudnia $2017 \mathrm{r}$.
} 
Mimo napiętych relacji z USA, Putin wciąż liczył na rozmowę z Trumpem na temat bezpieczeństwa międzynarodowego podczas szczytu Wspólnoty Gospodarczej Azji i Pacyfiku (APEC) 10-11 listopada 2017 r. ${ }^{36}$ Ostatecznie do dwustronnego spotkania nie doszło. Prawdopodobnie strona amerykańska uznała, że może to źle wpłynąć na wizerunek Trumpa.

18 grudnia 2017 r. w ogłoszonej Strategii bezpieczeństwa narodowego ponownie Rosję uznano za rywala. Dokument stwierdza jednoznacznie, że: „Chiny i Rosja aktywnie osłabiają bezpieczeństwo i wpływy USA. Rozwijają zdolności propagandowe, asymetryczne, konwencjonalne i nuklearne z zamiarem rewizji istniejącego ładu międzynarodowego, którego filarem Stany Zjednoczone planują pozostać, na rzecz zasad sprzecznych z wartościami ${ }^{37}$. Rosję oskarża się o stosowanie propagandy, dezinformacji podważającej procesy demokratyczne na świecie, lecz również o wzmacnianie zdolności wojskowych na obrzeżach Eurazji, w wyniku czego wzrasta ryzyko niezamierzonego konfliktu ${ }^{38}$.

Do oczekiwanej przez Władimira Putina zmiany stanowiska Donalda Trumpa doszło podczas spotkania G7, kiedy prezydent USA wyraził opinię, że Rosja powinna wrócić do grona najbogatszych państw świata, aby móc rozstrzygać problemy międzynarodowe. Wśród kontrowersyjnych wypowiedzi amerykańskiego polityka znalazła się i taka, w której zaznaczył, że Krym powinien należeć do Rosji, gdyż na półwyspie rozmawia się po rosyjsku. Odbył też spotkanie z Putinem na 16 lipca 2018 r., kilka dni po szczycie NATO w Brukseli. Motywów Trumpa do podjęcia takich działań było kilka. Po pierwsze, po historycznym szczycie z północnokoreańskim przywódcą Kim Dzong Unem (12 maja 2018 r.) Trump chciał powtórzyć wizerunkowy sukces, przenosząc ciężar stosunków wielostronnych na kontakty dwustronne, w których decydującą rolę odgrywają przywódcy państw ${ }^{39}$. Po drugie, spotykając się z Putinem chciał poszerzyć zakres swoich prerogatyw w polityce zagranicznej, ograniczonych w 2017 r. poprzez aferę z rosyjską ingerencją w wyborach prezydenckich. Wówczas Kongresowi udało się zmniejszyć obawy o jednostronne zniesienie sankcji przez Trumpa wobec m.in. Rosji. Jednocześnie ewentualne porozumienie Trumpa z Putinem może poważnie zaszkodzić transatlantyckiej solidarności nie tylko

36 W. RodKIEWICZ, Rozmowa Trump-Putin w Da Nang: fiasko Kremla, „Analizy OSW”, 15 listopad $2017 \mathrm{r}$.

${ }^{37}$ National Security Strategy of the United States of America, The White House, 2017, s. 2, $35,47$.

${ }^{38}$ M.A. PIOTROWSKI, B. WIŚNIEWSKI, Strategia bezpieczeństwa narodowego USA: podejście administracji Trumpa, „Biuletyn PISM” 2017, nr 128 (1570), 21 grudnia, www.pism.pl

39 O. Pietrewicz, Szczyt Kim-Trump: sukces Korei Pótnocnej, „Komentarz PISM” 42(2018), 15 maja $2018 \mathrm{r}$. 
w sprawie Ukrainy, lecz również porozumienia w ramach NATO dotyczącego wyzwań i strategii działania sojuszu.

\section{WNIOSKI}

Rywalizacja rosyjsko-amerykańska na Ukrainie wynika z przedmiotowego traktowania tego państwa przez oba mocarstwa. Federacja Rosyjska nie chce uznać podmiotowości międzynarodowej Ukrainy i jej prawa do decydowania o kierunku swojej polityki zagranicznej i bezpieczeństwa. Jednocześnie postrzega ten kraj jako miejsce wpływów obcych mocarstw - w tym przede wszystkim USA i Unii Europejskiej. Taka perspektywa nie pozwala władzom rosyjskim na pogodzenie się z aspiracjami euroatlantyckimi Ukrainy, w tym głównie z chęcią wstąpienia do NATO. Dlatego w perspektywie długoterminowej nie będzie chciała zrezygnować ze wsparcia udzielanego tzw. separatystom w Donbasie i za jego pośrednictwem - destabilizowania wewnętrznego Ukrainy.

Konflikt zbrojny w 2014 r. był momentem przełomowym dla państw zachodnich, które opowiedziały się po stronie państwa ukraińskiego, nie uznały aneksji Krymu oraz nałożyły sankcje na Rosję. Początkowo USA nie zdecydowały się na zaangażowanie w negocjacje na temat Donbasu ani nie chciały dostarczać broni do tego państwa, uznając, że powstrzymywanie Rosji powinno zatrzymać się na wzmocnieniu wschodniej flanki NATO. Ukraina zyskała jednak znaczącą pomoc finansową i wsparcie szkoleniowe dla armii. Dojście do władzy Donalda Trumpa niepokoiło władze ukraińskie, że może dojść do niekorzystnego dla nich kompromisu między prezydentem USA i Władimirem Putinem. Jednak amerykańska administracja i Kongres, udzielające pomocy finansowej i militarnej Ukrainie, dawały sygnały stałego wsparcia rządu ukraińskiego. Udało się odsunąc groźbę samodzielnego znoszenia sankcji przez Trumpa, o co zabiegali Rosjanie. Wręcz przeciwnie, USA przyjęły nowe regulacje prawne wobec Rosji, wzmocniły obostrzenia, uderzając bezpośrednio w otoczenie Władimira Putina. Niemniej Trump konsekwentnie realizuje swoje postulaty z kampanii wyborczej, podczas której wypowiadał się pozytywnie na temat możliwości współpracy z Rosją. Nie jest zatem wykluczone, że będą podejmowane takie próby. Pozostaje otwarte pytanie, czy Ukraina nie stanie się przedmiotem rozgrywki politycznej między USA i Rosją? Z analizy stosunków rosyjsko-amerykańskich wynika, że na ewentualnym zbliżeniu Federacja Rosyjska mogłaby wiele zyskać, ale jednocześnie ma niewiele do zaoferowania ze względu na swoje aspiracje międzynarodowe (wątpliwe, by zrezygnowała $\mathrm{z}$ zaangażowania w Syrii, bliskich kontaktów z Iranem lub aby wycofała się z Krymu). 


\section{BIBLIOGRAFIA}

BAEL D.B., If Trump Tries to Make a Deal with Putin, He's Already Lost, „Foreign Policy”, 30 stycznia $2017 \mathrm{r}$.

BAJOR P., „Operacja Krym” - aneksja półwyspu i jej konsekwencje, „Rocznik Instytutu Europy Środkowo-Wschodniej” 2(2014), z. 2.

BAJOR P., Ukraina chce do NATO, „Nowa Europa Wschodnia”, 7 września 2014 r., www.new.org.pl

Belkin P., Mix E.D., Woehrel S., NATO: Response to the Crisis in Ukraine and Security Concerns in Central and Eastern Europe, „Congressional Research Service”, 31 lipiec 2014 r.

Collins K., Herb J., Diaz D., Trump Signs Bill Approving New Sanctions Against Russia, „CNN", 8 lutego $2017 \mathrm{r}$.

DĄBROWSKi A., LEGUCKA A., Sankcje USA wobec Rosji, „Biuletyn PISM” 73(2017), 31 lipca.

DYNER, A.M. Spotkanie Trump-Putin w Hamburgu, „Komentarz PISM” 38(2017), 11 lipca.

Dyner A.M., Szeligowski D., Perspektywa operacji pokojowej ONZ w Donbasie, „Biuletyn PISM" 94(2017), 5 października.

General License No. 1 Authorizing Certain Transactions with the Federal Security Service, 2 lutego 2017 r., www.treasury.gov

Generał USA: Zostaniemy w krajach bałtyckich, jak długo będzie trzeba, PAP, 9 marca $2015 \mathrm{r}$.

KaCZMARski M., Polityka zagraniczna Rosji wobec USA, w: Polityka zagraniczna Rosji, red. S. Bieleń, M. Raś, Warszawa: Difin 2008, s. 48-49.

KAPUŚNIAK T., Ukraina jako obszar wpływów międzynarodowych po zimnej wojnie, WarszawaLublin: Instytut Europy Środkowo-Wschodniej 2008.

Koranyi B., Holland S., Mardiste D., Obama Says NATO Must Help Strengthen Ukraine's Military, „Reuters”, 3 września 2014 r.

LegucKa A., Polityka Baracka Obamy wobec Rosji, „Polski Przegląd Dyplomatyczny” 2(2017).

LEgUCKA A., The NATO-Ukraine Relations after the Annexation of Crimea, „Ukraine Analytica” 2(2017).

LEwICKi Z., Dziedzictwo Obamy - próba oceny, „Polski Przegląd Dyplomatyczny” 1(2017).

MenkiszaK M., Najlepszy nieprzyjaciel Rosji. Rosyjska polityka wobec USA w epoce Putina, „Punkt Widzenia OSW” 62(2017) (luty).

National Security Strategy of the United States of America, The White House, 2017.

National Security Strategy, The White House, luty 2015, http://nssarchive.us

On Final Ukraine Trip, Biden Urges Trump Administration to Keep Russia Sanctions, „The Guardian", 16 stycznia $2017 \mathrm{r}$.

Ostrovsky S., The Invention of Russia. The Journey from Gorbachev's Freedom to Putin's War, London: Atlantic Books 2015.

Pietrewicz O., Szczyt Kim-Trump: sukces Korei Północnej, „Komentarz PISM” 42(2018), 15 maja.

PIETROw N., Rosja przechodzi do natarcia, „Polski Przegląd Dyplomatyczny” 2(2018).

PIOTROWSKI M.A., WIŚNIEWSKI B., Strategia bezpieczeństwa narodowego USA: podejście administracji Trumpa, „Biuletyn PISM” 2017, nr 128 (1570), 21 grudnia, www.pism.pl

Rasmussen: Kraje NATO przeznaczą $15 \mathrm{mln}$ euro na wsparcie dla Ukrainy, „Newsweek”, 4 września 2014 r.

REAFFIRMING U.S. Commitment to a Sovereign and Whole Ukraine on the Third Anniversary of Russia's Crimean „Referendum”, Washington, DC, 16 marca 2017 r., https://www.state.gov

Rodkiewicz W., Rozmowa Trump-Putin w Da Nang: fiasko Kremla, „Analizy OSW”, 15 listopada $2017 \mathrm{r}$. 
Rogin J., Trump Administration Approves Lethal Arms Sales to Ukraine, „Washington Post”, 20 grudnia $2017 \mathrm{r}$.

SAKwA R., U.S.-Russian Relations in the Trump Era, „Insight Turkey” 19(2017), nr 4.

Sankcje USA, w: Sankcje i Rosja, red. J. Ćwiek-Karpowicz, S. Secrieru, Warszawa: PISM 2015, s. 26.

ShabAD R., Trump Administration Relaxes U.S. Sanctions on Russia Imposed under Obama, 2 lutego 2017 r., www.cbsnews.com.

Stent A.E., The Limits of Partnership. US-Russian Relationship in the Twenty-First Century, Princeton: Princeton University Press 2015.

Support for the Sovereignty, Integrity, Democracy, and Economic Stability of Ukraine Act of 2014, „Public Law” 2014, 113-195, Apr. 3, www.congress.gov

The Trump Administration and the Russia Probes, „Strategic Comments” 23(2017), nr 7.

Ukaz priezidienta Rossijskoj Fiedieracyi ot 30.09.2012 g., nr 1342 o nagrażdienii gosudarstwiennymi nagradami Rossijskoj Fiedieracyi inostrannych grażdan, 30 wrzesień 2012 r., www.kremlin.ru

Vaughan A., Choice of Rex Tillerson Could Revive US-Russia Energy Summits, „The Guardian”, 12 stycznia $2017 \mathrm{r}$.

WŁodKowsKa-BAgAn A., Rywalizacja mocarstw na obszarze poradzieckim, Warszawa: Difin 2013.

Wywiad NATO alarmuje: Rosjanie przerzucają nowe siły na Ukrainę, www.polskieradio.pl

\section{MIEJSCE UKRAINY W STOSUNKACH ROSYJSKO-AMERYKAŃSKICH PO 2014 ROKU}

\section{Streszczenie}

Celem niniejszego artykułu jest odpowiedź na pytanie, jakie miejsce zajmuje Ukraina w stosunkach między Rosją i USA. W pierwszej części podjęto w nim kwestię znaczenia Ukrainy dla interesów narodowych obu międzynarodowych rywali. Przyjęto perspektywę czasową po $2014 \mathrm{r}$. (od aneksji Krymu) do 2017 r. (wyborów prezydenckich w USA). W drugiej części ukazano ewolucję amerykańskiego podejścia do bezpieczeństwa Europy Wschodniej, w tym kwestię dozbrajania państwa ukraińskiego walczącego z rosyjskimi oddziałami. Trzecią część poświęcono konsekwencjom wydarzeń w Ukrainie, zarówno Euromajdanu, jak i wojny na wschodzie Ukrainy dla relacji USA i Rosji. W konkluzjach stwierdzono więc, że Ukraina stała się wyznacznikiem relacji między USA i Rosją, a rok 2014 stał się punktem zwrotnym w strategii USA wobec NATO. Doszło do wzmocnieniu wschodniej flanki sojuszu, a także nałożenia amerykańskich sankcji na Rosję.

Słowa kluczowe: Rosja; Ukraina; USA; bezpieczeństwo; polityka zagraniczna. 


\section{UKRAINE IN THE RUSSIAN-AMERICAN RELATIONS}

AFTER 2014

\section{S u m m a r y}

Russia and the US are the international rivals. The aim of the article is to examine at which conditions Ukraine is becoming an object or the subject of Russian-American rivalry? What interests does Russia and the US have in this country? Analyzing those questions, it will be used the comparable method to understand foreign policy of the US and Russia towards Ukraine. RussianUkrainian war in 2014 brought to the agenda the question of West's ability to react in such crises and to assist partners in spheres other than security sector reform. Americans tried to help Ukraine through the NATO, which approved the establishment of a common fund for long-term modernization of the Ukrainian armed forces, but this did not fulfill the Ukrainian aspirations towards NATO. At the same time Trump-Putin relations are still important factor in case of Ukraine.

Key words: Ukraine; Russia; Crimea; US; Trump; Putin. 